Syntax Literate: Jurnal Ilmiah Indonesia p-ISSN: 2541-0849 e-ISSN : 2548-1398

Vol. 6, Spesial Issue No. 1, November 2021

\title{
KELAYAKAN FINANSIAL ABON IKAN TUNA DI KOTA BONTANG
}

\author{
Said Abdusysyahid, Bambang Indratno Gunawan, Muhamad Syafril \\ Mulawarman University, Samarinda, Indonesia \\ Email: syahids59@yahoo.co.id, syafril@fpik.unmul.ac.id, \\ bambanggunawan1970@gmail.com
}

\begin{abstract}
Abstrak
Penelitian ini bertujuan untuk mengukur nilai kelayakan usaha pengolahan abon ikan tuna berdasarkan indikator R/C, Net Profit Margin (NPM), Titik Impas (Break Event Point), Masa Pengembalian Investasi (Payback Period) dan Return on Investment (ROI), dilaksanakan di wilayah Kota Bontang. Data dianalisis dengan menggunakan 1) analisis deskriptif yang bertujuan untuk mendeskripsikan gambaran umum wilayah dan profil usaha pengolahan 2) Analisis kelayakan usaha ditinjau dari aspek finansial, dengan menggunakan indikator efisiensi usaha (R/C), Titik Impas (BEP), Net Profit Margin (NPM), Masa Pengembalian Investasi (Payback Period) dan Return on Invesment (ROI). Hasil penelitian menunjukkan bahwa Nilai finansial dari produktivitas ini sebesar Rp200.000 - Rp720.000, dengan rata-rata Rp404.444 per hari per pengolah. Nilai efisiensi usaha (TR/TC) sebesar 1,23-1,58, dengan rata-rata 1,41. Nilai TR/TC > 1, sehingga usaha sudah berada pada kondisi efisien. Nilai Net Profit Margin usaha pengolahan abon ikan tuna di Kota Bontang sebesar 18,57\% - 36,57\%, dengan rata-rata 28,53\%. Kondisi aktual usaha pengolahan abon ikan tuna ditinjau dari jumlah penjualan, jumlah unit produksi dan harga jual per unit, berada di atas kondisi BEP. Nilai titik impas penjualan (BEP penjualan) sebesar Rp2.548.960 - Rp4.436.008, dengan rata-rata per pengolah Rp3.666.825. Titik impas produksi tercapai pada kisaran 116 kemasan - 149 kemasan, dengan rata-rata 137 kemasan per pengolah. Titik immpas dari harga jual per kemasan/bungkus yaitu Rp5.019 - Rp22.180, dengan rata-rata Rp11.191 Usaha pengolahan ini membutuhkan waktu untuk mengembalikan dana investasi selama 1,13 tahun - 42,53 tahun, dengan rata-rata 15,93 tahun. Nilai ROI pada usaha pengolahan abon ikan tuna sebesar $0,20 \%$ $7,38 \%$, dengan rata-rata $3,20 \%$.
\end{abstract}

Kata Kunci: kelayakan usaha; abon ikan tuna; pengolahan

\section{Abstract}

This study aims to measure the feasibility value of a shredded tuna fish processing business based on indicators of R/C, Net Profit Margin (NPM), Break Even Point (Break Event Point), Payback Period and Return on Investment (ROI), carried out in Bontang City area. The data were analyzed using 1) descriptive analysis which aims to describe the general description of the area and the profile of the processing business 2) Business feasibility analysis in terms of financial aspects, using indicators of business efficiency $(R / C)$, Break-even Point (BEP), Net Profit Margin (NPM), Payback Period and Return on Investment (ROI). The results

$\begin{array}{ll}\text { How to cite: } & \text { Abdusysyahid, S., Gunawan, B. I., \& Syafril, M. (2021) Kelayakan Finansial Abon Ikan Tuna di Kota } \\ & \text { Bontang. Syntax Literate: Jurnal Ilmiah Indonesia, 6(1). } \\ \text { E-ISSN: } & 2548-1398 \\ \text { Published by: } & \text { Ridwan Institute }\end{array}$


Said Abdusysyahid, Bambang Indratno Gunawan, Muhamad Syafril

showed that the financial value of this productivity was IDR 200,000 - IDR 720,000 , with an average of IDR 404,444 per day per processor. The value of business efficiency (TR/TC) is $1.23-1.58$, with an average of 1.41 . TR/TC value > 1, so the business is in an efficient condition. The value of the Net Profit Margin of shredded tuna processing business in Bontang City is $18.57 \%$ - 36.57\%, with an average of $28.53 \%$. The actual condition of the shredded tuna processing business in terms of the number of sales, the number of production units and the selling price per unit, is above the BEP condition. The break-even point value (BEP of sales) is IDR 2,548,960 - IDR 4,436,008, with an average per processor of IDR $3,666,825$. The break-even point was reached in the range of 116 packages -149 packages, with an average of 137 packages per processor. The break-even point of the selling price per pack/package is IDR 5,019 - IDR 22,180, with an average of IDR 11,191 This processing business takes 1.13 years -42.53 years to return investment funds, with an average of 15,93 years. The ROI value in the shredded tuna processing business is $0.20 \%-7.38 \%$, with an average of $3.20 \%$.

Keywords: business feasibility; abon tuna fish; Processing

Received: 2021-10-20; Accepted: 2021-11-05; Published: 2021-11-18

\section{Pendahuluan}

Upaya untuk meningkatkan nilai dan mengoptimalkan pemanfaatan produksi hasil tangkapan laut adalah dengan mengembangkan produk bernilai tambah, baik olahan tradisional maupun modern. Satu diantara pengolahan ikan yang banyak dilakukan kelompok masyarakat, baik industri rumah tangga maupun UMKM adalah produk abon ikan Tuna (Arman dan Ruslang, 2017).

Kota Bontang memiliki sentra produksi pengolahan komoditi perikanan seperti terasi udang, nugget ikan dan abon ikan tuna. Usaha pengolahan hasil perikanan ini telah cukup lama dikelola oleh masyarakat lokal sebagai penghasilan utama keluarga pengolah. Terdapat beberapa alasan yang menyebabkan pengolah hasil perikanan diantaranya abon ikan tuna dan terasi udang di wilayah masih bertahan menjalankan usaha ini, di antaranya adalah 1) Adanya ketersediaan bahan baku dari hasil tangkapan ikan dan udang sepanjang tahun, 2) Supplier bahan baku adalah nelayan yang berdomisili di kota Bontang, umumnya adalah kepala keluarga dari pengolah, 3) Usaha pengolahan merupakan upaya pemanfaatan waktu luang oleh wanita nelayan untuk dapat meningkatkan pendapatan keluarga, 4) pengolah telah memiliki skill khusus dalam pembuatan hasil olahan ikan seperti terasi dan abon ikan tuna, sehingga mampu menghasilkan produk olahan perikanan dengan kualitas yang baik, 5) olahann hasil perikanan memiliki wilayah pemasaran baik di kota bonatang mapun diluar Kota Bontang, kegiatan pemasaran olahan hasil perikanan melibatkan lembaga pemasaran, 6) Kota Bontang menjadi satu di antara kota wisata bahari yang ada di Kalimantan Timur, dan memiliki souvernir yang khas, diantaranya olahan perikanan berupa terasi dan abon ikan tuna, 7) usaha pengolahan hasil perikanan ini telah lama menjadi sasaran program kerja bagi pemerintah, karena kegiatan ekonomi dari usaha ini merupakan satu diantara upaya pemerintah untuk dapat meningkatkan ekonomi masyarakat lokal Kota Bontang, 
khususnya yang bergerak dibidang perikanan, dan pada akhirnya berdampak terhadap ekonomi daerah (Syafril dan Fidhiani, 2020).

\section{Metode Penelitian}

Penelitian ini dilakukan di Kota Bontang yang merupakan sentra produksi abon ikan tuna di Kalimantan Timur, Penelitian ini menggunakan pendekatan kuantitatif yang dipadukan dengan pendekatan kualitatif. Penelitian ini menggunakan 2 jenis data yaitu data primer (data utama penelitian) dan sata sekunder (data pendukung penelitian). Data primer bersumber dari observasi langsung ke lokasi penelitian (sumberdaya alam, sumberdaya manusia, sumberdaya wilayah, sumberdaya teknologi), wawancara dengan responden (pengolah, pemerintah). Data primer meliputi.

1. Identitas reponden

2. Kinerja usaha :

a. Biaya Produksi

b. Jumlah Produksi

c. Harga Jual Produk

d. Proses Produksi Abon Ikan Tuna

Data sekunder merupakan data pendukung penelitian, yang diperoleh melalui tinjauan sumber-sumber kepustakaan yang berkaitan dengan tujuan penelitian. Jenis data ini diperoleh melalui tinjauan kepustakaan. Data sekunder dalam penelitian ini meliputi

1. Monografi wilayah (kelurahan dan kota)

2. Hasil-hasil penelitian yang sesuai dengan tujuan penelitian

Data penelitian yang diperoleh, selanjutnya diproses melalui triangukasi data dan dan metode. Hal ini bertujuan untuk meningkatkan validitas data yang akan dianalisis, sehingga mampu menghasilkan kesimpulan dan rekomendasi yang sesuai dengan kondii aktual.

Sampel penelitian adalah pelaku usaha pengolahan abon ikan tuna yang masih aktif melakukan kegiatan produksi, yang berada di Kota Bontang. Terdapat 3 orang yang melakukan usaha pengolahan abon ikan tuna. Dengan demikian jumlah sampel penelitian adalah 3 orang pengolah. Pengambilan sampel menggunakan metode sensus. Semua anggota populasi dijadikan sebagai anggota sampel.

\section{Hasil dan Pembahasan}

\section{A. Kondisi Fisik Wilayah}

\section{a) Topografi}

Wilayah Kota Bontang didominasi oleh permukaan tanah yang datar, landai, dan sedikit berbukit dengan ketinggian antara $0-106 \mathrm{~m}$ di atas permukaan laut. Mayoritas wilayah (48\%) menempati kawasan pinggir pantai yang relatif datar, sehingga relief Kota Bontang terlihat mendatar di wilayah pantai, dan bergerak membukit dan bergelombang dari bagian Selatan ke arah Barat. 


\section{Tabel 1}

Sebaran Luas Kota Bontang berdasarkan Ketinggian di Wilayah Pesisir

\begin{tabular}{|c|c|c|c|c|c|c|c|}
\hline \multirow[b]{2}{*}{ No } & \multirow[b]{2}{*}{ Kecamatan } & \multirow{2}{*}{$\begin{array}{c}\text { Desa/ } \\
\text { Kelurahan }\end{array}$} & \multicolumn{5}{|c|}{ Luas berdasarkan Kelas Ketinggian (Ha) } \\
\hline & & & $\begin{array}{c}0-15 \\
\mathrm{~m}\end{array}$ & $\begin{array}{c}15-25 \\
\mathrm{~m}\end{array}$ & $\begin{array}{c}25-100 \\
m\end{array}$ & $\begin{array}{c}100-500 \\
\mathrm{~m}\end{array}$ & Jumlah \\
\hline \multirow{5}{*}{1} & \multirow{4}{*}{$\begin{array}{l}\text { Bontang } \\
\text { Utara }\end{array}$} & Loktuan & 86 & 166 & 178 & - & 430 \\
\hline & & Belimbing & 1.025 & 428 & 552 & - & 2.005 \\
\hline & & $\begin{array}{l}\text { Bontang } \\
\text { Baru }\end{array}$ & 303 & 487 & 100 & - & 890 \\
\hline & & $\begin{array}{l}\text { Bontang } \\
\text { Kuala }\end{array}$ & 579 & 6 & - & - & 585 \\
\hline & $\mathrm{J} \mathrm{u} \mathrm{m} \mathrm{l} \mathrm{a} \mathrm{h}$ & & 1.993 & 1.087 & 830 & - & 3.910 \\
\hline \multirow{6}{*}{2} & \multirow{5}{*}{$\begin{array}{l}\text { Bontang } \\
\text { Selatan }\end{array}$} & Satimpo & 486 & 782 & 8 & - & 2.122 \\
\hline & & $\begin{array}{l}\text { Tanjung } \\
\text { Laut }\end{array}$ & 573 & 127 & - & - & 700 \\
\hline & & $\begin{array}{l}\text { Berbas } \\
\text { Tengah }\end{array}$ & 26 & 208 & - & - & 234 \\
\hline & & $\begin{array}{l}\text { Berbas } \\
\text { Pantai }\end{array}$ & 102 & 3 & - & - & 105 \\
\hline & & $\begin{array}{l}\text { Bontang } \\
\text { Lestari }\end{array}$ & 2.235 & 1.415 & 4.893 & 20 & 7.709 \\
\hline & \multicolumn{2}{|l|}{ J u m lah } & 3.442 & 2.535 & 4.901 & 20 & 10.870 \\
\hline \multicolumn{3}{|c|}{ KOTA BONT } & 5.415 & 3.622 & 5.723 & 20 & 14.780 \\
\hline
\end{tabular}

Sumber: Badan Pusat Statistik Kota Bontang (2019)

\section{b) Klimatologi}

Wilayah Kota Bontang memiliki iklim tropis yang sama dengan wilayah lainnya di Indonesia pada umumnya. Wilayah Kota Bontang termasuk daerah khatulistiwa dan dipengaruhi iklim tropis basah dengan ciri-ciri khas hujan terjadi di sepanjang tahun dengan suhu rata-rata $24^{\circ}-33^{\circ} \mathrm{C}$. Oleh karena itu, di wilayah ini hampir tidak memiliki perbedaan pergantian musim hujan dan kemarau. Angin musim barat pada umumnya terjadi pada bulan November-April dan musim angin timur terjadi pada bulan Mei-Oktober.

\section{c) Kependudukan}

Penduduk Kota Bontang mengalami pertambahan setiap tahunnya. Keberadaan dua perusahaan besar berskala nasional yakni PT Badak NGL dan PT Pupuk Kaltim Tbk menjadi satu diantara pemicu terjadinya pertambahan penduduk tersebut. Pertambahan tersebut tidak hanya disebabkan faktor alami pertumbuhan penduduk yakni kelahiran dan kematian tetapi juga faktor lain yang tidak kalah pentingnya yakni migrasi. Jumlah penduduk Kota Bontang Tahun 2017 sudah mencapai 170.611 jiwa. Pertumbuhan penduduk Kota Bontang dari tahun 2010 - 2017 18,04\% (26.078 jiwa). Pertumbuhan penduduk selama 1 tahun (2016/2017) sebesar 2,24\% atau 3.743 jiwa. 
Tabel 2

Jumlah Penduduk Menurut Kecamatan

\begin{tabular}{lcccc}
\hline \multirow{2}{*}{ Kecamatan } & \multicolumn{3}{c}{ Jenis Kelamin } & Rasio Jenis \\
& Laki-laki & Perempuan & Jumlah & Kelamin \\
\hline 1. Bontang Selatan & 34.733 & 32.061 & 66.794 & 108,33 \\
\hline 2. Bontang Utara & 36.106 & 32.707 & 68.813 & 110,39 \\
\hline 3. Bontang Barat & 18.441 & 16.563 & 35.004 & 111,34 \\
\hline Bontang & 89.280 & 81.331 & 170.611 & 109,77 \\
\hline Sunn
\end{tabular}

Sumber: BPS Kota Bontang (2018)

Tabel 3

Laju Pertumbuhan Penduduk Kota Bontang

\begin{tabular}{lccccc}
\hline \multirow{2}{*}{ Kecamatan } & \multicolumn{3}{c}{ Jumlah Penduduk } & \multicolumn{2}{c}{$\begin{array}{c}\text { Laju Pertumbuhan } \\
\text { per Tahun }\end{array}$} \\
\cline { 2 - 6 } & $\mathbf{2 0 1 0}$ & $\mathbf{2 0 1 6}$ & $\mathbf{2 0 1 7}$ & $\mathbf{2 0 1 0 / 2 0 1 7}$ & $\mathbf{2 0 1 6 / 2 0 1 7}$ \\
\hline $\begin{array}{l}\text { 1. Bontang } \\
\text { Selatan }\end{array}$ & 57.771 & 65.551 & 66.794 & 15,62 & 1,90 \\
\hline 2. Bontang Utara & 61.717 & 67.883 & 68.813 & 11,50 & 1,37 \\
\hline 3. Bontang Barat & 25.045 & 33.434 & 35.004 & 39,76 & 4,70 \\
\hline Bontang & 144.533 & 166.868 & 170.611 & 18,04 & 2,24 \\
\hline
\end{tabular}

Sumber: BPS Kota Bontang (2018)

\section{B. Potensi Sumberdaya Perikanan}

1. Produksi dan Nilai Produksi

Kota Bontang yang merupakan satu di antara 10 kabupaten/kota yang terdapat di Provinsi Kalimantan Timur, memiliki luas wilayah 49.757 ha, terdiri dari 34.977 ha $(70,3 \%)$ wilayah laut dan 14.780 ha $(29,7 \%)$ wilayah daratan. Wilayah pesisir dan laut yang terbentang pada panjang garis pantai $24,4 \mathrm{~km}$, berada pada posisi Alur Laut Kepulauan Indonesia II (ALKI II) Selat Makassar, sedangkan wilayah daratan berada pada poros jalan Trans Kalimantan (Samarinda - Bontang - Sangatta). Potensi sumberdaya perikanan tangkap dan budidaya (marikultur) yang dimiliki oleh wilayah ini dapat dikelompokkan menjadi sumberdaya alam di perairan pesisir dan laut, sumberdaya manusia (SDM) dan sumberdaya modal (kapital) sebagaimana ditampilkan oleh tabel dibawah ini.

Tabel 4

Potensi Sumberdaya Perikanan Kota Bontang

\begin{tabular}{llcc}
\hline No & \multicolumn{1}{c}{ Indikator Potensi } & Satuan & Nilai \\
\hline $\mathrm{A}$ & Ekosistem Perairan Pesisir dan Laut & & \\
\hline 1 & Hutan Mangrove & $\mathrm{Ha}$ & $1.115,5$ \\
\hline 2 & Gosong Pulau $*$ & $\mathrm{Ha}$ & 940 \\
\hline 3 & Padang Lamun (sea grass) & $\mathrm{Ha}$ & 741 \\
\hline 4 & Terumbu Karang: & $\mathrm{Ha}$ & 6.454 \\
\hline & a. Kondisi Baik & $\mathrm{Ha}$ & 3.254 \\
\hline & b. Kondisi Rusak & $\mathrm{Ha}$ & 3.200 \\
\hline 5 & Area Marikultur Ikan dan Rumput Laut & $\mathrm{Ha}$ & 423 \\
\hline B & Sumberdaya Manusia dan Kapital & & \\
\hline 1 & Jumlah RTP Laut & & 3.181 \\
\hline 2 & Perahu/Kapal Perikanan & & 1.347 \\
\hline & a. Perahu tanpa motor & unit & 117 \\
\hline
\end{tabular}




\begin{tabular}{|c|c|c|c|}
\hline No & Indikator Potensi & Satuan & Nilai \\
\hline & b. Motor Tempel & Unit & 944 \\
\hline & c. Kapal Motor & Unit & 487 \\
\hline 3 & Jumlah alat tangkap di laut & Unit & 2.534 \\
\hline 4 & RTP Budidaya/Marikultur & KK & 652 \\
\hline 5 & Jumlah Nelayan & KK & \\
\hline $\mathrm{D}$ & Jumlah Produksi & & \\
\hline 1 & Perikanan Tangkap & Ton & $20.773,6$ \\
\hline 2 & Perikanan Budidaya & Ton & $6.390,7$ \\
\hline
\end{tabular}

RTP: Rumah Tangga Perikanan

Sumber: Dinas Perikanan, Kelautan dan Pertanian Kota Bontang (2016) dan BPS Kota Bontang (2018)

Sentra produksi perikanan tangkap berada di wilayah Tanjung Laut Indah, Berbas Pantai, Tanjung Limau dan Loktuan. Produksi perikanan budidaya laut (karamba tancap dan apung) dan kolam meliputi kerapu, kakap, baronang, kuwe, mas, nila dan lele. Namun demikian, jumlah produksi masih didominasi oleh komoditi rumput laut sebesar 98\%. Sentra produksi perikanan budidaya berada di wilayah Bontang Kuala, Tanjung Laut Indah, Berbas Pantai, Gunung Elai, Loktuan, Sekambing, Guntung dan Kanaan.

Usaha marikultur rumput laut maupun jenis ikan ekonomis penting perlu terus dikembangkan, baik melalui intensifikasi (teknik budidaya dan pasca panen, penggunaan bibit unggul dan pakan) maupun ektensifikasi (didalam dan luar perairan Kota Bontang melalui kerjasma antar pemda dan kelompok pembudidaya).

Jumlah produksi perikanan tangkap maupun budidaya belum mampu memenuhi permintaan untuk konsumsi komoditi ikan laut di Kota Bontang, Peningkatan jumlah produksi ini tidak mampu mengimbangi peningkatan konsumsi ikan di wilayah Kota Bontang, yang mengalami peningkatan sebesar $46,43 \%$.

\section{Profil Usaha}

Usaha pengolahan abon ikan tuna merupakan usaha turun temurun yang dilakukan oleh masyarakat pesisir Kota Bontang. Usaha ini sudah ada sejak beberapa tahun yang lalu oleh masyarakat pendatang dari Sulawesi maupun masyarakat lokalnya. Jumlah masyarakat lokal yang menjadi pengolah abon ikan tuna adalah 10 orang.

Pengetahuan dan keterampilan dalam mengolah abon ikan tuna ini diperoleh dari keluarga, kerabat, teman-teman satu profesi maupun dari media surat kabar, media elektronik dan penyuluhan yang dilakukan oleh pemerintah derah dalam hal ini Dinas Kelautan dan Perikanan Kota Bontang. 
Usaha pengolahan tini dilakukan secara individu oleh masyarakat, dan tidak tergabung dalam satu kelompok usaha bersama (KUB) bidang perikanan, sebagaimana usaha perikanan tangkap dan budidaya. Hal ini dikarenakan :

a) Usaha pengolahan abon ikan ini belum banyak ditekuni oleh masyarakat. Animo masyarakat untuk memenkuni usaha ini relatif masih rendah. Hal in dikarenakan bahan baku abon ikan ini yaitun ikan tuna tidak tersedia sepanjang tahun. Kalaupun ada, tentu harga jualnyanya cukup tinggi. Mengingat komoditi ikan ini termasuk komoidti eikan ekonomis penting, yang diekspor ke mancanegara.

b) Nelayan ikan tuna, belum mampu secara maksimal mendukung pengolah abon ikan ini, untuk dapat menyediakan bahan baku ikan tuna, dalam kondisi segar, dengan kualitas daging yang sangat baik. Komoditi ikan tuna ynag memiliki teksntur daging yang baik, umumnya dijual ke luar daerah atai ekspor dengan ahrga yang cukup tinggi. Hal ini menjadi kendala bagi pengolahan untuk dapat memperoleh bahan baku yang berkauliats denganb harga yang cukup terjangkau.

c) Pengolah abon ikan tuna adalah ibu rumah tangga nelayan, yang memiliki kegiatan domestik rumah tangga. Pekerjaan sebagai pengolah hanyalah pekerjaan sampingan untuk memanfaatkan waktu luang, memanfaatkan ikan tuna sebagai hasil tangkapan nelayan dan memperkuat ekonomi keluarga. Hal ini sesuai dengan hasil penelitian yang dilakukan oleh Arman dan Ruslang (2017), bahwa Pengolahan abon ikan di kota Parepare yang dilakukan oleh UMKM "Mekar" dengan melibatkan ibu rumah tangga yang bekerja sebagai tenaga borongan, yang memanfaatkan waktu serta kemampuan mereka untuk mendapatkan nilai tambah terhadap ikan tuna yang cukup mudah diperoleh di pasar.

Proses produksi abon ikan tuna berlangsung selama 1 hari, dimulai dari penyiapan bahan baku, pemasakan, pendinginan dan pengemasan. Produk abon ikan tuna yang dihasilkan oleh pengolah di kota bontang, dikemas dalam kemasan plastik, dengan ukuran berat 100 gram dan 250 gram. Terdapat 3 model siklus produksi dari 3 pengolah. Pengolah pertama memiliki 4 siklus produksi per minggu, pengolah kedua memiliki 1 siklus produksi per minggu, dan pengolah ke tiga memiliki 1 siklus produksi per 2 minggu. Abon ikan tuna yang dihasilkan oleh pengilah, dipasarkan didalam dan luar Kota Bontang seperti Sangatta, Samarinda dan Balikpapan. Harga jual abon ikan tuna ditingkat produsen atau pengolah adalah Rp.27.000 per kemasan 100 gram, Rp.22.000 - Rp.30.000 per kemasan 250 gram.

Pembukuan usaha yang digunakan oleh pengolah masih bersifat sederhana. Kegiatan transaksi, hanya tercatat pada buku yang disertai dengan nota pembelian atau penjualan. Pembukuan usaha belum menggunakan model pembukuan usaha, yang informatif dan mudah dilakukan.

\section{Lokasi Usaha}

Usaha pengolahan abon ikan tuna terletak di kelurahan pesisir Kota Bontang. Kegiatan pembuatan atau pengolahan ikan tuna dilakukan di rumah dengan memanfaatkan sarana prasarana rumah tangga yang dimiliki seperti bangunan rumah, air bersih, listrik, dan kompor gas. Bahan baku utama berupa ikan tuna diperoleh 
pelaku usaha dari pedagang pengumpul lokal yang berdomisili di Kota Bontang. Pedagang pengumpul ini memiliki nelayan binaan, yang telah lama melakukan penangkapan ikan tuna di Selat Makassar, dengan alat tangkap pancing. Lokasi usaha pedagang pengumpul ikan tuna adalah di wilayah pemukiman masyarakat nelayan, yang terletak di sepanjang wilayah pesisir Kota Bontang. Harga ikan tuna di tingkat pedagang pengumpul lokal berkisar Rp.25.000 - Rp.30.000 per kilo gram.

\section{E. Identitas Responden}

\section{Umur}

Umur merupakan salah satu faktor yang menentukan produktif atau tidaknya kinerja seseorang, tidak dapat dipungkiri bahwa umur juga merupakan salah satu faktor yang dapat menentukan keberhasilan seseorang dalam menjalankan sebuah usaha, terlepas dari pengalaman ataupun klasifikasi lainnya yang terdapat pada setiap individu, sehingga secara tidak langsung umur dapat berpengaruh pada kondisi fisik dan mental seseorang. Pada umumnya seseorang yang masing berumur muda cenderung memiliki kinerja dan kemampuan yang lebih bagus serta lebih prima dibandingkan dengan seseorang yang berumur lebih tua. Badan pusat statistik (2017), menyatakan usia produktif manusia berada pada kisaran usia 15-64 tahun. Pada tabel 1, dirincikan identitas umur dari responden yang di teliti.

Tabel 5

Umur Responden

\begin{tabular}{lccc}
\hline No & $\begin{array}{c}\text { Kriteria umur } \\
\text { (Tahun) }\end{array}$ & $\begin{array}{c}\text { Jumlah } \\
\text { (Orang) }\end{array}$ & $\begin{array}{c}\text { Persentase } \\
(\boldsymbol{\%})\end{array}$ \\
\hline 1 & $30-40$ & 1 & 33,33 \\
\hline 2 & $41-50$ & 2 & 66,67 \\
\hline Jumlah & & 3 & 100 \\
\hline
\end{tabular}

Sumber: Data Primer Diolah, 2021

Berdasarkan Tabel di atas, diketahui bahwa umur responden pada penelitian ini berada pada kisaran 30-50 tahun. Hal ini menunjukkan bahwa, seluruh pengolah abon ikan tuna berada pada usia produktif. Dengan demikian seluruh pelaku usaha memiliki tingkat produktivitas yang layak dalam menjalankan usaha ini.

\section{Pendidikan}

Pendidikan merupakan satu diantara yang harus ditempuh untuk mencapai kesuksesan, pendidikan memberi dampak atau hasil yang positif bagi setiap orang yang melaksanakannya. Melalui pendidikan seseorang mampu mengembangkan sebuah usaha. Tingkat pendidikan dapat mempengaruhi kecerdasan, wawasan, bahkan hingga karakter dan sikap seseorang. Tingkat pendidikan yang ditempuh oleh responden pada penelitian ini dapat dilihat pada tabel di bawah ini. 
Tabel 6

Tingkat Pendidikan Responden

\begin{tabular}{lccc}
\hline No & Tingkat Pendidikan & $\begin{array}{c}\text { Jumlah } \\
\text { (Orang) }\end{array}$ & $\begin{array}{c}\text { Persentase } \\
(\mathbf{\%})\end{array}$ \\
\hline 1 & SMA/SMK/SMU/SLTA & 2 & 66,67 \\
\hline 2 & Sarjana & 1 & 33,33 \\
\hline Jumlah & & 3 & 100 \\
\hline
\end{tabular}

Sumber: Data Primer Diolah, 2021

Berdasarkan data pada tabel di atas, diketetahui bahwa tingkat pendidikan dari responden adalah Sekolah Menengah Atas (SMA) dan Sarjana. Dengan tingkat pendidikan yang cukup tinggi ini, akan memudahkan responden pengolah untuk mengelola usaha secara efisien dan meningkatkan skala usaha menjadi lebih berorientasi bisnis perikanan. Usaha pengolahan abon ikan merupakan minabisnis yang memiliki prospek baik dimasa mendatang untuk dikembang sebagai matapencaharian utama masyarakat pesisir, sehingga menjadi instrument tersendiri dalam meningkatkan kesejahteraan masyarakat.

\section{Jumlah Tanggungan}

Jumlah tanggungan merupakan parameter yang digunakan untuk mengetahui banyaknya anggota keluarga yang ditanggung dan dinafkahi oleh kepala keluarga. Jumlah tanggungan yang merupakan cerminan jumlah anggota keluarga pengolah, dapat menjadi faktor pendorong bagi usaha ini. Anggota keluarga berperan sebagai tenaga kerja sukarela, pada usaha pengolahan abon ikan tuna, sehingga efisiensi penggunaan biaya produksi dapat tercapai secara maksimal. Jumlah tanggungan dari responden yang diteliti dapat dilihat pada tabel di bawah ini.

Tabel 7

Jumlah Tangguan Keluarga Responden

\begin{tabular}{cccc}
\hline 1 & $0-2$ & 2 & 66,67 \\
\hline 2 & $3-5$ & 1 & 33,33 \\
\hline & Jumlah & 3 & 100 \\
\hline
\end{tabular}

Sumber: Data Primer Diolah, 2021

Berdasarkan tabel di atas, diketahui jumlah tanggungan responden berada pada kisaran $2-5$ orang.

\section{F. Aspek Ekonomi Usaha Pengolahan Abon Ikan Tuna}

\section{Biaya Investasi}

Biaya investasi pada usaha pengolahan abon ikan tuna merupakan biaya yang harus dikeluarkan oleh pengolah ketika memulai usaha pengolahan biaya ini. Biaya investasi dikeluarkan pada tahun ke 0 usaha. Biaya investasi pada usaha pengolahan abon ikan tuna di Kota Bontang dapat dibagi menjadi 4 bagian yaitu investasi tanah atau lahan, investasi bangunan rumah produksi, investasi kendaraan atau alat transportasi dan investasi peralatan produksi. jumlah investasi 
pada usaha ini berkisar Rp.106.973.000 - Rp.568.609.000. komponen biaya investasi terbesar adalah bangunan rumah produksi, yang menyerap biaya investasi sebesar 42,07\% - 60,28\% dari total jumlah investasi.

Modal investasi usaha pengolahan abon ikan tuna, bersumber dari keluarga dan modal sendiri. Kebutuhan biaya investasi investasi pada usaha pengolahan ini, secara rinci ditampilkan pada tabel di bawah ini.

2. Biaya Operasional

Biaya operasional merupakan biaya produksi atau sejumlah korbanan dalam bentyk uang yang harus dikeluarkan oleh pengolah abon ikan tuna di Kota Bontang, pada saat melaksanakan proses produksi Biaya operasional sering juga diistilahkan sebagai modal kerja. Biaya operasional dalam usaha pengolahan ini terbagi menjadi 2 yaitu biaya tetap (fixed cost) dan biaya tidak tetap (variable cost).

Jumlah biaya tetap yang dikeluarkan oleh pengolah abon ikan tuna, bersifat statis, dalam jangka waktu tertentu, misalnya satu bulan, dan tidak dipengaruhi oleh jumlah abon ikan yang akan di produksi. Jumlah biaya variabel, bersifat dinamis, sangat ditentukan oleh jumlah abon ikan tuna yang akan diproduksi oleh pengolah. Biaya tetap meliputi biaya listrik, depresiasi dan biaya bensin pertalite. Biaya variabel dikelompokkan menjadi 3 yaitu biaya bahan baku ikan tuna, biaya bumbu, penyedap rasa dan minyak goreng, dan biaya kemasan. Rekapitulasi ratarata biaya operasional ditampilkan pada tabel berikut.

Berdasarkan tabel-tabel diatas, dapat diketahui bahwa, biaya operasional yang telah dikeluarkan oleh 3 orang pengolah abon ikan tuna berjumlah Rp4.885.917 - Rp13.701.306. Struktur biaya produksi usaha pengolahan abon ikan tuna terdiri dari biaya tetap dan biaya variabel. Terdapat perbedaan jumlah biaya operasional atau biaya produksi antar pengolah. Perbedaan ini disebabkan oleh jumlah siklus produksi per bulan. Pengolah ke 1 melakukan kegiatan produksi abon ikan sebanyak 4 kali dalam seminggu, sehingga terdapat 16 siklus produksi dalam 1 bulan. Pengolah ke 2 melakukan kegiatan produksi setiap 2 minggu sekali, sehingga dalam 1 bulan terdapat 2 siklus produksi, sedangkan pengolah ke 3 , kegiatan produksi abon ikan dilakukan setiap minggu, sehingga terdapat 4 siklus produksi dalam 1 bulan. Pengolah ke 1 memiliki jumlah siklus produksi yang lebih banyak, disebabkan produk abon ikan yang dihasilkan te;ah dipasarkan ke luar Kota Bontang yaitu Samarida dan Balikpapan, sedangkan pengolah ke 2 dan ke 3, produk dihasilkan hanya dipasarkan di dalam kota Bontang, serta konsumen luar kota yang datang langsung ke lokasi produksi.

3. Produksi, Penerimaan dan Keuntungan Usaha

Kondisi usaha pengolahan abon ikan tuna usaha diarahkan pada pencapaian kondisi ekonomi yang berorientasi bisnis (mina bisnis). Tujuan bisnis yang telah lana dikelola ini adalah memperoleh keuntungan maksimal melalui optimalisasi penggunaan input produksi. 
Jumlah produksi abon ikan tuna yang dihasilkan oleh masing-masing 3 orang pengolah berada pada kisaran 200 bungkus - 800 bungkus per bulan, atau $50 \mathrm{~kg}-224 \mathrm{~kg}$ per bulan dengan rata-rata, $125 \mathrm{~kg}$ per bulan. Harga jual yang berada pada kisaran Rp22.000 - Rp30.000 per bungkus, menghasilkan penerimaan sebesar Rp6.000.000 - Rp21.600.000, dengan rata-rata Rp12.133.333 per pengolah.

Pendapatan atau keuntungan atau laba bersih pada usaha pengolahan abon ikan tuna merupakan selisih antara hasil penjualan produk dengan biaya operasional atau biaya produksi per bulan. Jumlah pendapatan yang dihasilkan pada usaha ini sebesar Rp1.114.083 - Rp7.898.694, dengan rata-rata Rp3.897.400. perbedaan jumlah produksi abon tuna antar pengolah, merupakan penyebab utama terjadinya perbedaan pendapatan. Pengolah ke 1 memiliki pendapatan yang lebih tinggi dibandingkan pengolah ke 2 dan ke 3 . Hal ini menunjukkan jumlah produksi pengolah ke 1 lebih besar yaitu $224 \mathrm{~kg}$ per bulan, sedangkan pengolah ke 2 dan ke 3 hanya mampu menghasilkan abon ikan tuna sebanyak $50 \mathrm{~kg}$ dan $100 \mathrm{~kg}$ per bulan. Rekapitulasi produksi, penerimaan dan pendapatan ditampilkan pada tabel dibawah ini :

1. Analisis Kelayakan Finansial

Analisis finansial usaha pengolahan abon ikan tuna di Kota Bontang, menggunakan pendekatan kriteria investasi tidak terdiskonto. Kriteria ini tidak memperhitungkan adanya perubahan nilai uang dimasa kini dan masa mendatang. Analisis kelayakan finansial hanya diuji berdasarkan masa produksi selama 1 bulan. Indikator kelayakan finansial yang digunakan dalam penelitian ini adalah efisiensi usaha (R/C), Net Profit Margin (NPM), Titik Impas (Break Event Point), Masa Pengembalian Investasi (Payback Period) dan Return on Investment (ROI).

2. Analisis Efisiensi Usaha

Efisiensi usaha pengolahan abon ikan tuna di Kota Bontang, dihitung dengan menggunanak pendekatan rasio Jumlah penerimaan dari penjualan (Total Revenue efisensi usaha) dengan jumlah biaya produksi (Total Cost). Nilai rasio penerimaan dan biaya produksi ini sebesar $1,23-1,58$, dengan ratarata 1,41. Nilai TR/TC > 1, sehingga usaha sudah berada pada kondisi efisien. Setiap Rp1.000.000 biaya operasional atau biaya produksi yang telah dikorbankan pada usaha pengolahan abon ikan tuna mampu menghasilkan penerimaan dari penjualan sebesar Rp1.230.000 - Rp1.580.000, dengan ratarata per pengolahan sebesar Rp1.410.000. selain menghasilkan sejumlah penerimaan, usaha ini juga mampu menghasilkan laba bersih atau keuntungan sebesar Rp.230.000 - Rp580.000, dengan rata-rata Rp.410.000.

Hasil penelitian ini yang dilakukan oleh Arman dan Ruslang (2017) menunjukkan bahwa Pengolahan abon ikan Tuna di kota Parepare yang dilakukan oleh UMKM "Mekar", secara finansial menguntungkan karena nilai efisiensi usaha (R/C) sebesar 1,65, dengan jumlah pendapatan Rp 141.692.100. 
Analisis ini bertujuan untuk mengukur kemampuan usaha pengolahan abon ikan dalam menghasilkan laba bersih, yang didasarkan pada jumlah penjualan (omset) yang dihasilkan. Analisis ini merupakan rasio antara laba bersih dengan jumlah penjualan abon ikan tuna. Analisis Net Profit Margin merupakan bagian dari pengukuran profitabilitas usaha.

Nilai Net Profit Margin usaha pengolahan abon ikan tuna di Kota Bontang sebesar $18,57 \%-36,57 \%$, dengan rata-rata $28,53 \%$. Nilai NPM yang dihasilkan memberikan penafsiran bahwa setiap Rp1.000.000 penjualan abon ikan tuna mampu menghasilkan laba bersih atau keuntungan bagi pelaku usahanya sebesar Rp185.681 - Rp365.680, dengan rata-rata per pelaku usaha Rp285.280. Nilai NPM sangat dipengaruhi oleh jumlah penjualan yang mampu diperoleh oleh pelaku usaha, dalam hal ini pengolah abon ikan di Kota Bontang. Semakin besar nilai NPM, maka sebaik baik usaha tersebut menghasilkan keuntungan. Berdasarkan nilai NPM, maka usaha pengolahan abon ikan berada pada kondisi yang baik dalam menhasilkan keuntunga, pendapatan auatu laba bersih bagi pelaku usahanya.

Analisis titik impas bertujuan untuk mengetahui kondisi aktual usaha pengolahan abon ikan berdasarkan aspek penjualan, jumlah produksi abon ikan dan harga jual per unit selama 1 bulan proses produksi. Apabila kondisi aktual usaha ini berada di atas nilai kondisi titik impas (BEP), maka usaha ini dapat dinyatakan menguntungkan dan layak secara finansial.

Berdasarkan aspek penjualan, nilai titik impas penjualan (BEP penjualan) sebesar Rp2.548.960 - Rp4.436.008, dengan rata-rata per pengolah Rp3.666.825. Kondisi penjualan aktual yang berada pada kisaran nilai Rp6.000.000 - Rp21.600.000, dengan rata-rata Rp12.133.333 per pengolah, berada diatas kondisi penjualan BEP, sehingga usaha layak secara finansial dijalankan.

Berdasarkan aspek jumlah produksi abon ikan tuna, titik impas produksi tercapai pada kisaran 116 kemasan - 149 kemasan, dengan rata-rata 137 kemasan per pengolah. Jumlah produksi aktual berada diatas kondisi BEP dari aspek produksi, yaitu 200 kemasan - 800 kemasan dengan rata-rata 467 kemasan.

Berdasarkan aspek harga jual per unit, kondisi BEP tercapai pada kisaran pada kisaran harga jual per kemasan/bungkus yaitu Rp5.019 - Rp22.180, dengan rata-rata Rp11.191. Harga jual aktual berada pada kisaran Rp22.000 Rp30.000, sehingga kondisi BEP berada dibawah kondisi aktual, dengan demikian usaha layak dijalankan.

Analisis ini bertujuan untuk mengukur lama waktu yang dibutuhkan oleh usaha pengolahan abon ikan tuna di Kota Bontang, didalam mengembalikan seluruh biaya investasi yang telah dikorbankan dalam usaha ini.

Usaha pengolahan ini membutuhkan waktu untuk mengembalikan dana investasi selama 1,13 tahun - 42,53 tahun, dengan rata-rata 15,93 tahun. Lama 
pengembalian investasi sangat ditentukan oleh jumlah biaya investasi yang telah dikorbankan oleh pengolah. Pengolah ke 2 telah mengorbankan biaya investasi yang besar yaitu Rp568.609.000, sehingga memerlukan waktu yang sangat lama untuk mengembalikan dana investasi tersebut, disisi lain, jumlah produksi abon ikan tuna yang dihasilkan, relatif kecil. Dengan demikian usaha yang dilakukan oleh pengolah ke 2 tidak layak secara finansial, sedangkan usaha yang dilakukan oleh pengolah ke 1 dan ke 2 layak secara, karena payback period hanya berlangsung 1,1 tahun dan 4,13 tahun.

Analisis ini bertujuan untuk mengukur kemampuan modal investasi yang dikorbankan dalam usaha pengolahan abon ikan tuna, didalam menghasilkan laba bersih atau pendapatan atau keuntungan bagi para pelaku usaha ini.

Nilai ROI pada usaha pengolahan abon ikan tuna sebesar $0,20 \%-7,38 \%$, dengan rata-rata $3,20 \%$. Nilai ini memberikan penafsiran bahwa, setiap Rp1.000.000 modal investasi yang ditanamkan pada usaha ini, mampu menghasilkan laba bersih, pendapatan atau keuntungan sebesar Rp1.959 Rp73.838, dengan rata-rata Rp31.995. Nilai ROI dalam rupiah per bulan adalah Rp658.224 - Rp92.840. Nilai suku bunga deposito Bank BRI untuk tenor 1 bulan sampai 3 bulan dengan nominal simpanan di bawah Rp 100 juta, dan Rp 100 juta sampai Rp 2 miliar adalah sebesar 2,75\%, dengan demikian usaha pengolahan abon ikan tuna yang dikelola oleh pengolah ke 2 tidak layak secara finansial, namun pengolah ke 1 dan ke 3, dan secara rata-rata layak secara finansial. Nilai ROI > suku bunga deposito per bulan dari BRI ; 2,85\%. Hasil analisis kelayakan finansial dapat dilihat pada tabel di bawah ini.

\section{Kesimpulan}

Berdasarkan hasil dan pembahasan, Usaha pengolahan abon ikan tuna, layak secara finansial. Nilai efisiensi usaha (TR/TC) sebesar 1,23-1,58, dengan rata-rata 1,41. Nilai TR/TC > 1, sehingga usaha sudah berada pada kondisi efisien. Setiap Rp1.000.000 biaya operasional atau biaya produksi yang telah dikorbankan pada usaha pengolahan abon ikan tuna mampu menghasilkan penerimaan dari penjualan sebesar Rp1.230.000 - Rp1.580.000, dengan rata-rata per pengolah sebesar Rp1.410.000.

Nilai Net Profit Margin usaha pengolahan abon ikan tuna di Kota Bontang sebesar $18,57 \%$ - 36,57\%, dengan rata-rata 28,53\%. Nilai NPM yang dihasilkan memberikan penafsiran bahwa setiap Rp1.000.000 penjualan abon ikan tuna mampu menghasilkan laba bersih atau keuntungan bagi pelaku usahanya sebesar Rp185.681 - Rp365.680, dengan rata-rata per pelaku usaha Rp285.280.

Kondisi aktual usaha pengolahan abon ikan tuna ditinjau dari jumlah penjualan, jumlah unit produksi dan harga jual per unit, berada di atas kondisi BEP. Nilai titik impas penjualan (BEP penjualan) sebesar Rp2.548.960 - Rp4.436.008, dengan rata-rata per pengolah Rp3.666.825. Titik impas produksi tercapai pada kisaran 116 kemasan 149 kemasan, dengan rata-rata 137 kemasan per pengolah. Titik immpas dari harga jual per kemasan/bungkus yaitu Rp5.019 - Rp22.180, dengan rata-rata Rp11.191. 
Said Abdusysyahid, Bambang Indratno Gunawan, Muhamad Syafril

Usaha pengolahan ini membutuhkan waktu untuk mengembalikan dana investasi selama 1,13 tahun - 42,53 tahun, dengan rata-rata 15,93 tahun. Nilai ROI pada usaha pengolahan abon ikan tuna sebesar 0,20\% - 7,38\%, dengan rata-rata 3,20\%. Nilai ini memberikan penafsiran bahwa, setiap Rp1.000.000 modal investasi yang ditanamkan pada usaha ini, mampu menghasilkan laba bersih, pendapatan atau keuntungan sebesar Rp1.959 - Rp73.838, dengan rata-rata Rp31.995. Nilai ROI > 2,75\% (suku bunga deposito Bank BRI per 3 bulan). 


\section{BIBLIOGRAFI}

Abidin, Z. (2018). Buku Ajar "Manajemen Agribisnis Perikanan. Program Studi Agribisnis Perikanan, FPIK, Universitas Brawijaya, Malang

Anjarsari, B. 2010. Pangan Hewani: Fisiologi Pasca Mortem dan Teknologi, Graha Ilmu

Arman dan Ruslang T. 2017. Analisis Finansial Usaha Abon Ikan Tuna (Thunnus Sp) Produksi UMKM Kota Parepare. Jurnal Pendidikan Teknologi Pertanian, Vol. 3 (2017) : 174-179

Astuti,D.R.D. 2017. Ekonomika Agribisnis (Teori dan Kasus). ISBN : 978-602-117533-0. Rumah Buku Carabaca, Universitas Negeri Makassar

Badan Pusat Statistik Kota Bontang. 2019. Kota Bontang Dalam Angka.

Botutihe, N.A. 2017. Analisis Rasio Profitabilitas Laporan Laba Rugi Pada Home Industri Cita Rasa Pagimana Kabupaten Banggai. Jurnal EMOR Vol. 2, No. 2, hal. $33-46$

Djamin, Z. 1992. Perencanaan Dan Analisis Proyek. Fakultas Ekonomi Universitas Indonesia. Jakarta.

Dzulmawan, M., Laode Geo), Abdul Gafaruddin. 2019. Analisis Nilai Tambah Pengolahan Abon Ikan Tuna di Kelurahan Mata Kecamatan Kendari Kota Kendari (Studi Kasus Industri Rumah Tangga Dzakiyah Permata). Jurnal Ilmiah Agribisnis (Jurnal Agribisnis dan Ilmu Sosial Ekonomi Pertanian). 2019:4(2):2934.

Ekowati, T., D Sumarjono, A Setiadi. 2020. Buku Ajar Studi Kelayakan dan Evaluasi Proyek. Fakultas Peternakan Dan Pertanian Universitas Diponegoro, Semarang

Fouren, Y. E., Dethan, Zainal Arifin Pua Geno. 2018. Analisis Kelayakan Usaha Pengolahan Abon Ikan Skala Rumah Tangga di Kota Kupang. Jurnal Agromina Vol.1, No.1, Juni 2018. ISSN 2615-6393

Herjanto, E. 2007. Manajemen Operasi. Edisi ke-3. Grasindo, Jakarta.

Jumingan, D. 2006. Analisis Laporan Keuangan. PT. Bumi Aksara, Jakarta 
Said Abdusysyahid, Bambang Indratno Gunawan, Muhamad Syafril

Mesra, B. 2016. Penerapan Ilmu Matematika Dalam Ekonomi dan Bisnis. Edisi 1 Cetakan ke 1. Deepublish (Grup Penerbit CV. Budi Utama), Yogyakarta

Nurgiyantoro, B., Gunawan, Marzuki, 2015. Statistik Terapan Untuk Penelitian Ilmu Sosial. Gadjah Mada University Press, Yogyakarta

Nurmala, Dewi Triana, Sutomo Mokodompit, Alumi. 2019. Analisis Profitabilitas Usaha Pembuatan Abon Ikan Tuna ( Studi Kasus Pada Usaha Wanita Mandiri ) di Kelurahan Sidoarjo Kecamatan Baolan Kabupaten Tolitoli. J. Agroland 26 (1) :14 - 20, April 2019. ISSN : 0854-641X . E-ISSN :2407-7607

Olivia, H. 2019. Penerapan Analisis Roi (Retrun On Investment) Untuk Memprediksi Pendapatan Perusahaan. KITABAH: Volume 3. No. 2 Juli - Desember 2019

Sugiyono (2015). Metode Penelitian Kombinasi (Mixed Methods). Alfabeta, Bandung

Syafril, M. Elly Purnamasari, Juliani, Heru Susilo. 2012. Skema permodalan dan pola kemitraan untuk usaha perikanan rakyat dalam upaya pengentasan kemiskinan di wilayah pesisir Kota Bontang, Provinsi Kalimantan Timur. Universitas Mulawarman, Samarinda

Syafril, M, Dayang Diah Fidhiani. 2020. Kelayakan finansial usaha pengolahan terasi udang rebon di kelurahan Bontang Kuala kota Bontang provinsi Kalimantan Timur. Jurnal AGROMIX. Volume 11 No 1 (2020), Halaman: 33-48. p-ISSN: 2085-241X ; e-ISSN: 2599-3003.

Uyunun, Ernik Yuliana, Mala Nurilmala. 2020. Analisis Prospektif Usaha Abon Ikan (Kasus: Cv Aroma Food Kota Banda Aceh) PELAGICUS: Jurnal IPTEK Terapan Perikanan dan Kelautan Vol.1 No.3: 123-134, September 2020

\section{Copyright holder:}

Said Abdusysyahid, Bambang Indratno Gunawan, Muhamad Syafril (2021)

First publication right:

Syntax Literate: Jurnal Ilmiah Indonesia

This article is licensed under:

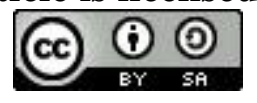

